\title{
Amylin induces hypoglycemia in mice
}

\author{
LUIZ H. GUERREIRO ${ }^{1 *}$, DANIEL DA SILVA ${ }^{1 *}$, MAURO SOLA-PENNA ${ }^{1}$, \\ DANIELLA M. MIZURINI ${ }^{2}$ and LUÍS M.T.R. LIMA ${ }^{1,3}$ \\ ${ }^{1}$ Faculdade de Farmácia, Universidade Federal do Rio de Janeiro/ UFRJ, \\ CCS, Bloco B, subsolo, sala 34, Av. Carlos Chagas Filho, 373, Ilha do Fundão, 21941-902 Rio de Janeiro, RJ, Brasil \\ ${ }^{2}$ Instituto de Bioquímica Médica, Universidade Federal do Rio de Janeiro/ UFRJ, \\ CCS, Bloco H, $2^{\circ}$ andar, sala 10, Av. Carlos Chagas Filho, 373, Ilha do Fundão, 21941-902 Rio de Janeiro, RJ, Brasil \\ ${ }^{3}$ Laboratório de Biotecnologia (Labio), INMETRO - Instituto Nacional de Metrologia, Qualidade e Tecnologia, \\ Av. N. Sa. das Graças, 50, Xerém, 25250-020 Duque de Caxias, RJ, Brasil
}

Manuscript received on November 23, 2011; accepted for publication on June 29, 2012

\begin{abstract}
Amylin is a 37-aminoacid pancreatic protein that exerts control over several metabolic events such as glycemia and lacticemia. Amylin has long been shown to induce increases in arterial plasma glucose. We decided to investigate whether amylin plays additional roles in the glucose metabolism. We evaluated glucose homeostasis using whole blood from the tail tip of fasting, conscious, unrestrained normal and streptozotocyn-induced diabetic mice following subcutaneous administration of mouse amylin. Subcutaneous injection of $1 \mu \mathrm{g}$ mouse amylin caused a transient decrease in whole blood glucose in both normal and diabetic mice in the absence of insulin. The blood glucose levels were lowest approximately 2 hours after amylin administration, after that they gradually recovered to the levels of the control group. The hypoglycemic effect followed a dose-dependent response ranging from 0.1 to $50 \mu \mathrm{g} /$ mouse. These results reveal the ability for amylin in the direct control of glycemia at low doses in the absence of insulin.
\end{abstract}

Key words: amylin, islet associated polypeptide, glycemia, diabetes, mice, hypoglycemia.

\section{INTRODUCTION}

Amylin, also known as islet associated / amyloid polypeptide (IAPP), is a 37-residue protein which is carboxy-amidated and contains a disulfide bridge between cysteines Cys2 and Cys7. Amylin is stored and co-secreted with insulin (Hartter et al. 1991) in response to various metabolic conditions. Plasma amylin concentrations depends on the body's metabolic conditions and are typically in the range of 2 to $20 \mathrm{pM}$ in fasting and fed conditions, respectively (Butler et al.

\footnotetext{
* These authors contributed equally to this work Correspondence to: Luís Maurício T.R. Lima E-mail:1ml@ufrj.br
}

1990), and at reduced levels or entirely absent in diabetic individuals (Hartter et al. 1990).

Soon after the discovery of amylin as a pancreatic deposit (Cooper et al. 1987, Westermark et al. 1987), the initial attempts to elucidate its effects on carbohydrate metabolism failed. The limited solubility of human amylin in aqueous solution results in the lack of biological activity, whereas water-soluble mouse/rat (same sequence) amylin does exhibit bioactivity (Bretherton-Watt et al. 1990, Balasubramaniam et al. 1991, Young et al. 1991).

Subsequent studies using high amylin doses and anesthetized animal models allowed the collection of relatively large arterial blood volumes and 
enabled a greater variety of biochemical analyses. Since then, amylin has been found to be involved in the regulation of glycemia, lacticemia, food intake, gastric emptying and the secretion of insulin and glucagon (Young 2005). The hyperglycemia induced by subcutaneous or intravenous administration of amylin is preceded by an increase in plasma lactate and has been observed in the arterial blood of both fasting and fed anesthetized rats and mice (Wang et al. 1991, 1992, Young et al. 1991, 1996). This hyperglycemia is attributed to the combined, dose-dependent effects of amylin's inhibition of insulin and glucagon secretion and its stimulation of gluconeogenesis (Young 2005). One study also found a greater effect of amylin on the liver compared with the peripheral tissues (Koopmans et al. 1991).

These effects of amylin on arterial blood glucose and other metabolites have been reported in the literature for over two decades. However, most data have resulted from measurements of the arterial blood of anesthetized animals. Halothane, isoflurane and other common anesthetic compounds have systemic metabolic effects including decreasing insulin secretion and causing hyperglycemia, hypocalcemia and hyperlactemia (Bito and Eakins 1969, Young et al. 1991, Wang et al. 1991, Farrokhnia et al. 2009, Zuurbier et al. 2008). Therefore, they might interfere in the measurement of discrete metabolic and physiological events.

In this context, we decided to investigate whether amylin exerts any additional roles in glucose metabolism. To address this issue, we evaluated the effects of mouse amylin on glycemia in fasting, conscious unrestrained mice by monitoring the whole blood glycemia in mice tail tips (Ayala et al. 2010). We report here a dose-dependent, transient decrease in blood glucose induced by subcutaneous mouse amylin. These data introduce a new physiological role for amylin, which in conjunction with the wellknown hyperglycemic effects of amylin, highlights the importance of its participation in the tight hormonal regulation of homeostasis.

\section{MATERIALS AND METHODS}

REAGENTS

Mouse amylin (CAS 122384-88-7) was obtained from GenScript (cat. \# RP11280, lot \#55613-1 and \#128567001040611LQ; mouse amylin is identical in sequence to rat amylin). Distilled water was deionized to less than $1.0 \mu \mathrm{S}$ and filtered through a $0.22 \mu \mathrm{m}$-pore membrane in a water purification system prior to use. All other reagents were of analytical grade. All buffers and solutions were prepared immediately prior use.

\section{Pharmacological EVALUation of Amylin}

Eight-weeks-old Swiss male mice (27 g $\pm 1 \mathrm{~g})$ were divided into four major groups: normal (both control and amylin) and diabetic (both control and amylin). The animals were housed in a temperaturecontrolled room with a 12:12 hours light-dark cycle. Type 1 diabetes was induced by one intraperitoneal (ip.) injection of STZ $(200 \mathrm{mg} / \mathrm{kg})$ dissolved in fresh citrate buffer (100 mM, pH 4.5) (Da et al. 2010, $\mathrm{Wu}$ and Huan 2008, Xu et al. 2006, Ogawa et al. 1990). Normal (non-diabetic) group received just the vehicle $(0.1 \mathrm{~mL})$. After STZ administration (5 days), blood was drawn from mice by tail snip and glucose level was evaluated as described below. Diabetes was defined as blood glucose concentration higher than $300 \mathrm{mg} / \mathrm{dL}$. Water and food were available ad libitum, and food was suspended $4 \mathrm{~h}$ before the experiments. All mice were fasted throughout the experiments and kept at constant temperature. The first group received either $100 \mu \mathrm{L}$ of saline (0.9 $\% \mathrm{NaCl})$ or phosphate buffered saline $(8.1 \mathrm{mM}$ $\mathrm{Na}_{2} \mathrm{HPO}_{4}, 1.8 \mathrm{mM} \mathrm{KH}_{2} \mathrm{PO}_{4}, 2.7 \mathrm{mM} \mathrm{KCl}, 137 \mathrm{mM}$ $\mathrm{NaCl}, \mathrm{pH}$ 7.4) as described in the figure legends. The second group received $100 \mu \mathrm{L}$ of the test solutions at varying doses. Solutions were administrated by subcutaneous injection using a standard 29-gauge needle. Glucose concentrations were monitored by using whole blood from the tail tip of the conscious, unrestrained mice using pre-calibrated glucometers 
(Accu-Chek ${ }^{\circledR}$ Active, Roche Diagnostics, Germany; Serial Nos GC02476995 and GN08146937) before injection and at repeated intervals after administration for up to 20 hours. This protocol is in accordance with the recommendations of the Mouse Metabolic Phenotyping Center Consortium (MMPC) from the National Institutes of Health (NIH) for animal experimentation and for evaluating the effects of metabolic compounds on glucose homeostasis (Ayala et al. 2010), and followed the 'Principles of laboratory animal care' (NIH publication no. 85-23, revised 1985). A control performance test was conducted by evaluating of the insulin-induced hypoglycemia and glucose-induced hyperglycemia using the same experimental protocol (not shown). Amylin activity was confirmed by evaluating the hyperglycemic effect of $100 \mu \mathrm{g}$ mouse (=rat) amylin (subcutaneous) on rats (approx. weight $370 \mathrm{~g}$ ) fasted for 5 hours and anesthetized with halothane using arterial blood taken from the carotid artery (Wang et al. 1991, Young et al. 1991). This study was approved by the Institutional Bioethics Committee on Animal Care and Experimentation (IBCACE) at UFRJ.

\section{STATISTICAL ANALYSIS}

A paired t-test was used to compare the differences in pharmacological response. Values of $p<0.05$ were considered significant. The analyses were performed using SigmaStat within SigmaPlot 11 (Systat Software Inc).

\section{RESULTS}

To understand the effects of amylin on glucose metabolism, we have monitored the glycemic effects of murine amylin in mice. Swiss male mice were fasted for 4 hours before subcutaneous administration of $100 \mu \mathrm{L}$ of either saline or $1 \mu \mathrm{g}$ mouse amylin in saline, and changes in glycemia were monitored at given intervals with blood taken from the tail tip of conscious, unrestrained mice (Fig. 1). Amylin resulted in the depression of the whole blood glucose levels in normal (i.e., nondiabetic) mice for the test group compared to the control group receiving saline only within the first 2 hours after administration (Fig. 1A). Approximately 6 hours after treatment the glycemia of both groups had converged to similar levels (Fig. 1A).

We have further evaluated the effect of amylin over the glycemia of streptozotocin-induced diabetic mice (Da et al. 2010, Wu and Huan 2008, $\mathrm{Xu}$ et al. 2006, Ogawa et al. 1990). Amylin was administrated through subcutaneous route and glycemia was monitored from whole blood. Amylin administration resulted in a rapid reduction of blood glucose within a few hours followed by a progressive restoration of glycemia to similar level of the control group, i.e., streptozotocin-induced diabetic mice receiving saline (Fig. 1B).
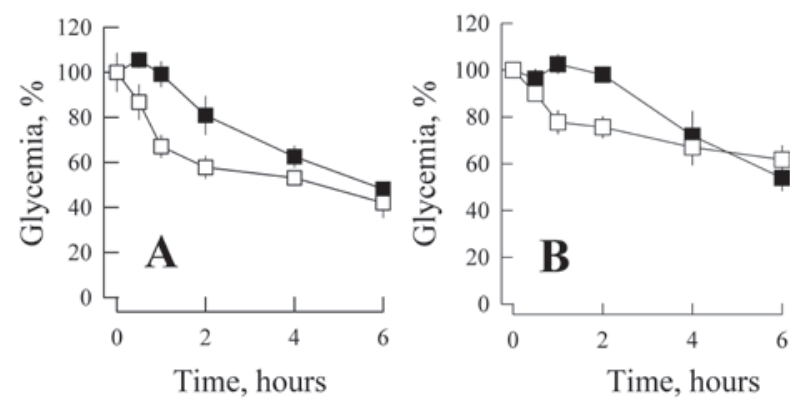

Figure 1 - Amylin induces hypoglycemia in fasting mice. Either a control solution ( $\square, 0.9 \%$ saline) or mouse amylin ( $\square, 1 \mu \mathrm{g}$ in $0.9 \%$ saline) was administered via subcutaneous injection in $4 \mathrm{~h}$-fasted mice ( $\mathrm{n}=4$ per group), both $\mathbf{A}$ ) normal (non-diabetic) and $\mathbf{B}$ ) streptozotocininduced type-1 diabetic mice. Glycemia was monitored using blood collected from the tail tip while the mice were fasting, conscious and unrestrained. Hypoglycemia was observed in the amylin-treated group ( $p=0.008 ; 2 \mathrm{~h}, p=0.05)$. Symbols represent mean \pm s.e.m. Further details can be found in the Methods section.

We further analyzed the relative changes in glycemic values induced by amylin. The normalized glycemic values showed a transient behavior, whereby the maximum decline in blood glucose occurred approximately 1 to 2 hours after amylin administration, followed by a progressive recovery of glycemic values to normal levels (Fig. $2)$. These results were reproducible regardless of 
room temperature $\left(19\right.$ or $\left.24{ }^{\circ} \mathrm{C}\right)$, amylin solution composition $(0.9 \% \mathrm{NaCl}$ saline or PBS buffer), analyst, glucosemeter equipment, amylin batch or the origin (vivarium) of the mice (Fig. 2).

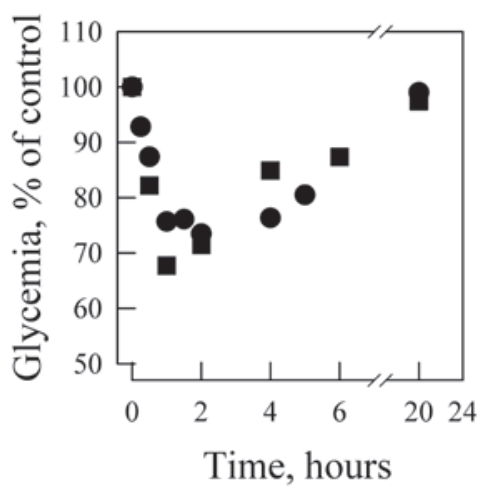

Figure 2 - Time-dependence on the hypoglycemia response to subcutaneous mouse amylin. Mice were treated with either amylin (1 $\mu \mathrm{g}$ in either saline or PBS solution) or a control solution of either saline or PBS administered via subcutaneous injection in $4 \mathrm{~h}$-fasted mice ( $\mathrm{n} \geq 3$ per group). Glycemia was monitored using blood collected from the tail tip while the mice were fasting, conscious and unrestrained. The results from the treatment group were subtracted from the control group, and the results are expressed here as percentage change. Experiments were performed by different analysts at $25{ }^{\circ} \mathrm{C}(\boldsymbol{\bullet})$ or 19 ${ }^{\circ} \mathrm{C}(\bullet)$, by using either $0.9 \%$ saline $(\boldsymbol{\bullet})$ or PBS $(\bullet)$ as the amylin diluting solution, using different glucometers, amylin batch and animals from distinct vivarium. Further details can be found in the Methods section.

We further evaluated the effects of varying the amylin dose on glycemia (Fig. 3). At very low doses $(0.01 \mu \mathrm{g} /$ mouse $)$ there was no observable effect compared to the control. Higher doses led to a progressive decrease in glycemic values, achieving a level approximately $80 \%$ of that of the control mice. In summary, a small but sensitive ability to decrease glycemic values was observed with doses from 0.1 to approximately $50 \mu \mathrm{g}$ amylin / mouse.

\section{DISCUSSION}

Amylin physiology and pharmacology has been studied intensely for two decades by independent laboratories. Amylin induces hyperglycemia in vivo regardless of the model studied, rat, mouse or human, in both normal and diabetic individuals. To

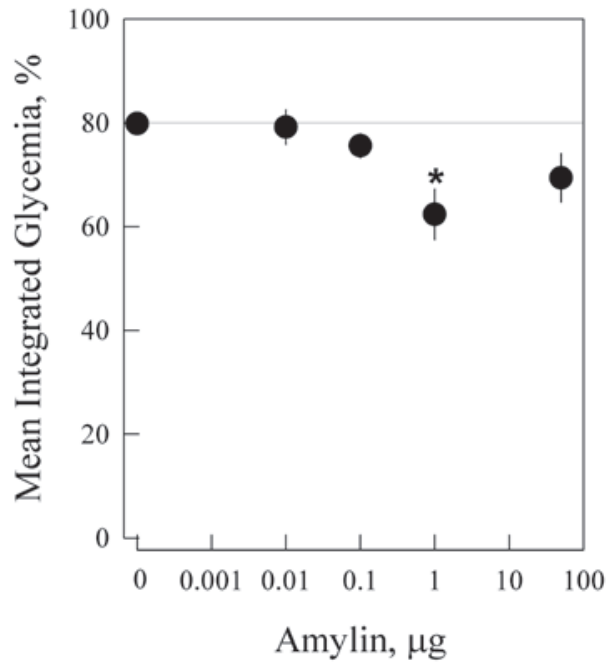

Figure 3 - Amylin dose-response for the decrease in whole blood glycemia. Mouse amylin was administered via subcutaneous injection in 4 h-fasted mice ( $n=4$ per group). Their glycemia was monitored from whole blood collected from the tail tip. The glycemia for each mouse (Fig. 1) was integrated over time for 1-6 h after administration of the mouse amylin and the plotted points represents the mean \pm s.e.m. as a function of the respective amylin dose.. $* p<0.02$ (unpaired t-test). Further details can be found in the Methods section.

date, hypoglycemic effects have not been reported, even at supraphysiological doses of amylin (Nyholm et al. 1996).

In the present study, we evaluated the hypoglycemic effects of subcutaneous mouse amylin using whole blood collected from the cut tail tip of mice. The observed hypoglycemic effects occurred over a small concentration range, with the maximum effect at $1.0 \mu \mathrm{g} /$ mouse, decreasing at higher doses. This effect was not restricted to murine amylin, since a hypoglycemic effect in mice was also observed using human amylin released from polymeric nanoparticles (Guerreiro et al. 2012) and from phosphatidylcholine liposomes using the same experimental pharmacology protocol reported here. These results provide further evidences that the hypoglycemic effects are not isolated attributes of mouse amylin or a device or formulation concern, but are most likely a general, physiological response to circulating amylin. We have also shown here that type 
1-diabetic mice were fully responsive to amylin in the absence of insulin, suggesting a direct role of amylin in controlling glycemia.

Our present findings do not contradict the hyperglycemic effects reported previously. Instead, we consider that the hypoglycemia reported here is peripheral and occurs to a small but significant extent in a concentration-dependent manner. This concentration dependence occurs over a different range from that observed for hyperglycemia in arterial plasma; the latter occurs over a large extent, making it difficult to observe a discreet, peripheral hypoglycemic effect.

Collectively, these data suggest that amylininduced hyperglycemia and hypoglycemia events are both reliable, dose-dependent effects, exerting their effect at both physiologic (low concentration) and pharmacologic (high concentration) conditions. Furthermore, they also suggest the existence of a relationship between local trends in glucose homeostasis and the different activities of amylin at varying sites, such as specific organs, tissues, interaction and signaling mechanism, at distinct concentration ranges. The hypoglycemic effect reported here introduces a new physiological and pharmacological action of amylin in living individuals. Further studies are needed to advance the understanding on how amylin affects biological systems.

\section{CONCLUSIONS}

Amylin is a pancreatic hormone known for acting over a large series of physiologic phenomena, including the regulation of glucose homeostasis, and is absent or present in reduced level in diabetes. In the present study we have shown that amylin can directly induces hypoglycemia in fasting, conscious unrestrained mice, in a dose-dependent hypoglycemic effect of amylin. Data support a new physiologic activity for amylin. We do believe that both the hypoglycemic and hyperglycemic effects of amylin are of equal importance, thought clear separated events regarding tissue specificity, physiopathologic conditions, and depend on the concentration range for the hormone at the site of action. Our data provides a landmark view on new physiologic functions for such an important hormone, and may open new perspectives in the study of system biology involving amylin.

\section{ACKNOWLEDGMENTS}

We would like to thank Prof. Ana L. P. Miranda and Rogerio A. Panizzutti for the helpful support. This research was supported by Coordenação de Aperfeiçoamento de Pessoal de Nível Superior (CAPES), Conselho Nacional de Desenvolvimento Científico e Tecnológico $(\mathrm{CNPq})$ and Fundação Carlos Chagas Filho de Amparo à Pesquisa do Estado do Rio de Janeiro (FAPERJ). The funding agencies had no role in the study design, data collection, data analysis, decision to publish or preparation of the manuscript. All authors have contributed to the conception and design or analysis and interpretation of the data, drafting the article, revising it critically for important intellectual content and have given their final approval of the version to be published.

\section{RESUMO}

Amilina é uma proteína de 37 aminoácidos que exerce controle sobre diversos eventos metabólicos, tais como glicemia e lacticemia. Tem sido mostrado que amilina induz aumento da glicemia plasmática arterial. Nós decidimos investigar se amilina exerce função adicional na regulação do metabolismo de glicose. Nós avaliamos a homeostase de glicose empregando sangue total da ponta da cauda de camundongos normais e diabéticos em condição livre de anestésico e não-confinados. Injeção subcutânea de $1 \mu$ g por camundongo causou o decréscimo transiente na glicemia tanto em camundongos normais quanto em diabéticos na ausência de administração de insulina. Os níveis de glicose atingiram o mínimo em aproximadamente 2 horas após administração de 
amilina, seguido por gradual restauração a níveis do grupo controle. O efeito hipoglicemiante demonstrou ser dose-dependente na faixa de 0,1 to $50 \mu \mathrm{g}$ / camundongo. Esses resultados revelam a abilidade de amilina exercer direto controle sobre a glicemia em baixas dose na ausência de insulina.

Palavras-chave: amilina, polipeptídeo pancreático amilóide, glicemia, diabetes, camundongos, hipoglicemia.

\section{REFERENCES}

Ayala JE, SAMuel VT, Morton GJ, OBici S, CRONiger CM, SHULMAN GI, WASSERMAN DH AND MCGUINNESS OP. 2010. Standard operating procedures for describing and performing metabolic tests of glucose homeostasis in mice. Dis Model Mech 3: 525-534.

Balasubramaniam A, RenUgopalakrishnan V, Stein M, Fischer JE and Chance WT. 1991. Syntheses, structures and anorectic effects of human and rat amylin. Peptides 12: 919-924.

BITO LZ AND EAKINS KE 1969. The effect of general anesthesia on the chemical composition of blood plasma of normal rabbits. J Pharmacol Exp Ther 169: 277-286.

BRETHERTON-WATt D, Gilbey SG, GHATEI MA, BEACHAM J AND BLOOM SR. 1990. Failure to establish islet amyloid polypeptide (amylin) as a circulating beta cell inhibiting hormone in man. Diabetologia 33: 115-117.

Butler PC, Chou J, Carter WB, Wang YN, Bu BH, ChANG D, ChANG JK AND RizzA RA. 1990. Effects of meal ingestion on plasma amylin concentration in NIDDM and nondiabetic humans. Diabetes 39: 752-756.

CoOPer GJ, Willis AC, Clark A, TURNer RC, Sim RB AND REID KB. 1987. Purification and characterization of a peptide from amyloid-rich pancreases of type 2 diabetic patients. Proc Natl Acad Sci USA 84: 8628-8632.

Da Silva D, Zancan P, Coelho WS, Gomez LS and SolaPENNA M. 2010. Metformin reverses hexokinase and 6-phosphofructo-1-kinase inhibition in skeletal muscle, liver and adipose tissues from streptozotocin-induced diabetic mouse. Arch Biochem Biophys 496: 53-60.

FARROKHNIA F, LEBASCHI AH AND ANDALIB N. 2009. A randomized clinical trial for the effects of halothane and isoflurane anesthesia on blood glucose levels in the diabetic patients. DARU J Pharm Sci 17: 29-32.

Guerreiro LH, Da Silva D, Ricci-Junior E, Girard-Dias W, Mascarenhas CM, Sola-Penna M, Miranda K AND LIMA LM. 2012. Polymeric particles for the controlled release of human amylin. Colloids Surf B Biointerfaces 94: 101-106.

HartTer E, Svoboda T, Lell B, Schuller M, Ludvik B, Woloszczuk W and Prager R. 1990. Reduced isletamyloid polypeptide in insulin-dependent diabetes mellitus. Lancet 335: 854.
Hartter E, Svoboda T, Ludvik B, Schuller M, Lell B, Kuenburg E, Brunnbauer M, WoloszczuK W AND PRAGER R. 1991. Basal and stimulated plasma levels of pancreatic amylin indicate its co-secretion with insulin in humans. Diabetologia 34: 52-54.

KOOPMANS SJ, VAN MANSFELD AD, JANSZ HS, KRANS HM, Radder JK, Frolich M, DE Boer SF, Kreutter DK, ANDREWS GC AND MAASSEN JA. 1991. Amylin-induced in vivo insulin resistance in conscious rats: the liver is more sensitive to amylin than peripheral tissues. Diabetologia 34: 218-224.

Nyholm B, Moller N, Gravholt CH, Orskov L, Mengel A, Bryan G, Moyses C, Alberti KG AND Schmitz O. 1996. Acute effects of the human amylin analog AC137 on basal and insulin-stimulated euglycemic and hypoglycemic fuel metabolism in patients with insulindependent diabetes mellitus. J Clin Endocrinol Metab 81: 1083-1089.

OgaWA A, HARRIS V, MCCORKLE SK, UNGER RH AND LUSKEY KL. 1990. Amylin secretion from the rat pancreas and its selective loss after streptozotocin treatment. J Clin Invest 85: 973-976.

WANG MW, CARLO P, FinEMAN M, RINK TJ AND YOUNG AA. 1992. Induction of acute hyperglycemia, hyperlactemia and hypocalcemia in fed and fasted BALB/c mice by intravenous amylin injection. Endocr Res 18: 321-332.

WANG MW, CARlo P, Rink TJ AND Young AA. 1991. Amylin is more potent and more effective than glucagon in raising plasma glucose concentration in fasted, anesthetized rats. Biochem Biophys Res Commun 181: 1288-1293.

Westermark P, WeRnStedt C, Wilander E, HAYdEN DW, O'BRIEN TD AND JOHNSON KH. 1987. Amyloid fibrils in human insulinoma and islets of Langerhans of the diabetic cat are derived from a neuropeptide-like protein also present in normal islet cells. Proc Natl Acad Sci USA 84: 3881-3885.

Wu KK AND HuAn Y. 2008. Streptozotocin-induced diabetic models in mice and rats. Curr Protoc Pharmacol Chapter 5.

Xu G, Kaneto H, Lopez-Avalos MD, WeIR GC AND BonnerWEIR S. 2006. GLP-1/exendin-4 facilitates beta-cell neogenesis in rat and human pancreatic ducts. Diabetes Res Clin Pract 73: 107-110.

Young A. 2005. Amylin: Physiology and Pharmacology. $1^{\text {st }}$ ed., Elsevier Academic Press, p. 1-18.

Young AA ET AL. 1996. Preclinical Pharmacology of Pramlintide in the rat: comparisons with human and rat amylin. Drug Dev Res 37: 231-248.

Young AA, WANG MW AND CoOPER GJ. 1991. Amylin injection causes elevated plasma lactate and glucose in the rat. FEBS Lett 291: 101-104.

ZuUrbier CJ, KeIJZers PJ, Koeman A, VAN WeZel HB AND HollmanN MW. 2008. Anesthesia's effects on plasma glucose and insulin and cardiac hexokinase at similar hemodynamics and without major surgical stress in fed rats. Anesth Analg 106: 135-142. 